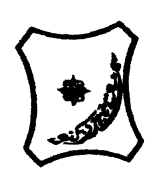

Bayero Journal of Pure and Applied Sciences, 12(1): 90 - 96

Received: November, 2018

Accepted: March, 2019

ISSN $2006-6996$

\title{
MECHANOCHEMICAL SYNTHESIS: A SUITABLE METHOD TO THE SYNTHESIS OF SOME DIAMINES SCHIFF BASES
}

\author{
- ${ }^{1}$ Sani,S., ${ }^{2}$ Kurawa, M. A., ${ }^{2}$ Siraj, I. T., and ${ }^{3}$ Koki, I. B. \\ ${ }^{1}$ Department of Pure and Applied Chemistry, Usmanu Danfodiyo University, P.M.B. 2346, Sokoto, \\ Nigeria \\ ${ }^{2}$ Department of Pure and Industrial Chemistry, Bayero University Kano, P.M.B 3011, Kano, Nigeria. \\ ${ }^{3}$ Department of Chemistry, Yusuf Maitama Sule University Kano, P.M.B 3220, Kano, Nigeria.
}

'Correspondence author:salihu_sani2001@yahoo.com

\begin{abstract}
Condensation of solid primary aromatic diamines (1,3-Phenylenediamine and 3,6diaminoacridine), with substituted aromatic aldehydes (2-hydroxy-1-naphthaldehyde and 2-hydroxy-3-methoxybenzaldehyde) afforded Schiff bases in quantitative yield under liquid-assistant grinding efficiently in the presence of DMF as a liquid assisted solvent. structural identification was done based on spectroscopic data. The Schiff bases were investigated by analytical and spectroscopic techniques using FT-IR, Powder X-ray Diffraction, Energy Dispersive X-ray (EDX), Differential scanning calorimetry and CHN microanalysis. Evidence from Infrared spectral study indicated a strong band in the spectra of $\left(H_{2} L^{\prime}\right)$ and $\left(H_{2} L^{\prime \prime}\right)$ Schiffbases appearing at $1634 \mathrm{~cm}^{-1}$ and $1638 \mathrm{~cm}^{-1}$ respectively assignable to azomethine band $(C=N)$. The Powder-XRD analysis reveals that, the patterns of the ground mixture were entirely different from the starting constituents, indicating that, all the starting materials were transformed to product, furthermore the melting point and colour of the Schiff bases were different from that of the starting constituents indicating the formation of new phase of the products. The compounds have also been screened for antimicrobial activities and shown potent antibacterial and antifungal activity. The operational effectiveness, environmentally friendly conditions and high yield achieved by this technique are major benefits that meet the requirements of green production.
\end{abstract}

Keywords: Mechanochemistry, Schiff base, Diamines, Antibacterial, Antifungal.

\section{INTRODUCTION}

Mechanochemistry can simply be described as a synthetic methodology induced by the input of mechanical energy and involves reactions in the solid state(Braga et al., 2007).In another approach, mechanochemistry corresponds to the chemical reaction achieved by grinding bulk solid reactants either manually, using a mortar and pestle, or using a ball mill(James et al., 2012). Mechanochemistry encompasses not only neat grinding, NG (no addition of solvent), but also liquid-assisted grinding (LAG), which consists on the use of catalytic amounts of a solvent to accelerate the reaction, it also comprises ion liquid-assisted grinding (ILAG), that involves the use of small amounts of a solvent and an ionic salt(Friščić et al., 2006). Mechanochemistry is rapidly becoming a method of choice in different areas of chemical and materials synthesis, namely: organic solids with pharmaceutical properties, Studies of biomolecular recognition, coordination polymers, metal-organic frameworks (MOFs), asymmetric catalysis
(Friščić, 2010; James et al., 2012). In fact, recently several coordination compounds have been prepared by this method and the use of solid-state techniques appears to be a powerful alternative to the commonly used solution-based methods, requiring milder conditions, and shorter reaction times (Quaresma et al., 2017). By way of example, HKUST-1 (Hong Kong University of Science and Technology), a porous network, was synthesized using neat grinding and also using LAG from copper(II) acetate monohydrate and benzene-1,3,5-tricarboxylic acid. The resulting compound has shown comparable BET (Brunauer Emmet \& Teller) surface area to that of samples obtained by conventional solution-based routes (Stolar et al., 2017).These syntheses were found to be highly efficient in terms of time and in avoidance of bulk solvent during the reaction. This work demonstrates the applicability of liquid-assistant mechanochemical synthesis to one-pot singlestep strategy. 
BAJOPAS Volume 12 Number 1, June, 2019

One of the important roles of Schiff bases is as an intermediate in the biologically important transamination reaction. They are used as a protective agent in natural rubber (George et al., 1993)and as an amino protective group in organic synthesis. The discovery and development of antibiotics are among the most powerful and successful achievements of modern science and technology for the control of infectious diseases(Sachdeva et al., 2012). However, the increasing microbial resistance to antibiotics necessitates the search for new agents with potential effects against pathogenic bacteria. The most magnificent advances in medicinal chemistry have been made when heterocyclic compounds played an important role in regulating biological activities.

\section{MATERIALS AND METHODS}

The reactions were carried out in a mortar by grinding with pestle. Reagents used were obtained from Sigma Aldrich UK and were used without further purification. Solid state Infrared spectra were recorded on a Perkin-Elmer FTIR Spectrum-400. Powder X-ray diffraction measurements were carried out on a PAN analytical Empyrean X'Pert Pro X-ray diffractometer. Energy dispersive X-ray (EDX) were determined using FESEM/EDX Hitachi brand with model SU8220.Differential scanning calorimetry (DSC) were carried out using TA DCS Q20 V24.10 instrument with cooling accessories of -180 to $350^{\circ} \mathrm{C}$. Elemental microanalysis of separated solid chelates for $\mathrm{C}, \mathrm{H}$ and $\mathrm{N}$ were determined using a Perkin-Elmer CHNS/O 2400 series II microanalyse, at University of Malaya, Malaysia

\section{Synthesis of Schiff base}

\section{2,2'-[1,3-}

Phenylenebis(nitrilomethylidyne)] bisnaphthol; $\left(\mathbf{H}_{\mathbf{2}} \mathbf{L}\right)$ Schiff base

2-hydroxy-1-naphthaldehyde, (0.3444g; 2mmol) and 1,3-phenylenediamine $(0.1081 \mathrm{~g} ; 1 \mathrm{mmol})$ were weighed in to agate motor, a small amount of DMF $(0.1 \mathrm{ml})$ was added to allow the formation of paste during grinding and the mixture was ground for $30 \mathrm{~min}$ to obtained yellow powder. the compound was left on an open air for $12 \mathrm{~h}$ at room temperature to dry. The dried product was ground for $3 \mathrm{~min}$ and weighed(Cinčić and Kaitner, 2011).<smiles>O=Cc1c(O)ccc2ccccc12</smiles><smiles>Nc1cccc(N)c1</smiles><smiles>C[13CH][13CH]</smiles><smiles>Oc1ccc2ccccc2c1/C=N/c1cccc(/N=C/c2c(O)ccc3ccccc23)c1</smiles>

Scheme 1: Synthetic reaction of $\mathrm{H}_{2}\left(L^{\prime}\right)$ Schiff base

6,6'-Dimethoxy-2,2'-[3,6Acridinebis(nitrilomethylidyne)] phenol; $\left(\mathrm{H}_{\mathbf{2}}(\mathrm{L} ")\right.$ Schiff base 2-hydroxy-3-methoxybenzaldehyde $(0.3043 \mathrm{~g} ; 2 \mathrm{mmol})$ and 3,6-diaminoacridine $(0.4775 \mathrm{~g} ; 1 \mathrm{mmol})$ were weighed carefully in to agate motor. A small amount of DMF $(0.1 \mathrm{ml})$<smiles>CCOc1cccc(O)c1O</smiles>

was added to allow the formation of paste

bisduring grinding and the mixture was ground for 30min to obtained a brownpowder. The compound was left in an open air for $12 \mathrm{~h}$ at room temperature. The dried product was ground for $3 \mathrm{~min}$ and weighed(Cinčić and Kaitner, 2011).<smiles>COc1cccc(/C=N/c2ccc3cc4ccc(/N=C/c5cccc(OC)c5O)cc4nc3c2)c1O</smiles>

Scheme 2: Synthetic reaction of $\mathrm{H}_{2}\left(\mathrm{~L}^{\prime}\right)$ Schiff base

\section{CHN Analysis}

The sample under test analysis was weighed in using tin capsule $(3 \mathrm{mg})$. The tin capsule containing the sample was than folded and placed in the autosampler. The tin capsule enclosing the sample fell into the reactor chamber where excess oxygen was introduced at about $990{ }^{\circ} \mathrm{C}$. The complete oxidation is reached at tungsten trioxide catalyst which is passed by gaseous reaction products. The resulting mixture consist of $\mathrm{CO}_{2}, \mathrm{H}_{2} \mathrm{O}$, and $\mathrm{NO}_{x}$ (Patil et al., 2014). 
BAJOPAS Volume 12 Number 1, June, 2019

\section{Powder X-ray diffraction}

Small amount of sample was grinded to a fine powder to minimize inducing extra strain that can offset peak positions, and to randomize orientation. The grinded sample was place into a sample holder. The sample holder was then placed in the power $x$-ray machine. The intensity of diffracted $\mathrm{x}$-rays was continuously recorded as the sample and detector rotate through their respective angles.

\section{Antimicrobial Sensitivity Test}

The antimicrobial activities of the Schiff base ligands were performed in vitro by agar well diffusion method. The Schiff base ligands were dissolved separately in dimethylsulfoxide to prepare three different concentrations $\left(60 \mathrm{mgml}^{-}\right.$ $1,30 \mathrm{mgml}^{-1}$ and $15 \mathrm{~m} \mathrm{gml}^{-1}$ ). The standard Inocula of the isolate were swabbed on to the surface area of the prepared and solidified agar plates. The test compounds, the standard antibiotic Ciprofloxacin (bacterial standard) and Ketoconazole (fungal standard) were placed in the agar well of the inoculated plates. The plates were incubated at $37^{\circ} \mathrm{C}$ for 24 hours and zone of inhibitions were recorded(Aspa et al., 2008).

\section{RESULTS AND DISCUSSION}

Experimentally,liquid-assisted mechanochemical conversionof selected aromatic aldehyde and primary aromatic amines to the corresponding Schiff base proceeded in a straight-forward manner. The two target Schiff bases, were successfully synthesized as observed from physical properties and microanalytical parameters shown inTable 1.

Table 1: Physical properties and Elemental Microanalysis of the Schiff Bases

\begin{tabular}{cccccccc}
\hline Compound & $\begin{array}{c}\text { Molecular } \\
\text { formula }\end{array}$ & Colour & Yield (\%) & Melting point & \multicolumn{3}{c}{ Found (Calculated) (\%) } \\
& & & $\left({ }^{\circ} \mathrm{C}\right)$ & $\mathrm{C}$ & $\mathrm{H}$ & $\mathrm{N}$ \\
\hline$\left(\mathrm{H}_{2} \mathrm{~L}^{\prime}\right)$ & $\mathrm{C}_{28} \mathrm{H}_{20} \mathrm{~N}_{2} \mathrm{O}_{2}$ & Yellow & 92.5 & 123 & $80.38(80.47)$ & $4.57(4.84)$ & $6.96(6.73)$ \\
$\left(\mathrm{H}_{2} \mathrm{~L}^{\prime \prime}\right)$ & $\mathrm{C}_{29} \mathrm{H}_{23} \mathrm{~N}_{3} \mathrm{O}_{4}$ & Brown & 77.4 & 80.2 & $73.28(72.94)$ & $5.17(4.85)$ & $8.59(8.80)$ \\
\hline
\end{tabular}

The Schiff bases $\left(\mathrm{H}_{2}\left(\mathrm{~L}^{\prime}\right)\right.$ and $\left(\mathrm{H}_{2}\left(\mathrm{~L}^{\prime \prime}\right)\right.$ has yellow and brown colour respectively. The Schiff bases were found to be soluble in polar solvents, methanol, ethanol, DMSO, DMF, Acetone and Acetonitrile but insoluble in non-polar solvent, the hexane. The solubility of the synthesized compounds in common polar solvent was due to the polar nature the Schiff bases. (Table 2). The elemental analysis of the Schiff base ligands for $\mathrm{C}, \mathrm{H}, \mathrm{N}$ (Table 1) are consistent with the calculated results from the empirical formula of the proposed structure of each compound.

Table 2: Solubility Test of Schiff Bases

\begin{tabular}{ccccccccc}
\hline Compound & Methanol & Ethanol & DMSO & DMF & Hexane & Acetone & Acetonitrile \\
\hline$\left(\mathrm{H}_{2} \mathrm{~L}^{\prime}\right)$ & $\mathrm{SS}$ & $\mathrm{S}$ & $\mathrm{S}$ & $\mathrm{S}$ & $\mathrm{IS}$ & $\mathrm{S}$ & $\mathrm{SS}$ \\
$\left(\mathrm{H}_{2} \mathrm{~L}^{\prime \prime}\right)$ & $\mathrm{S}$ & $\mathrm{S}$ & $\mathrm{S}$ & $\mathrm{S}$ & $\mathrm{IS}$ & $\mathrm{S}$ & $\mathrm{S}$ \\
\hline
\end{tabular}

Where $\mathrm{S}$ - Soluble SS - Slightly Soluble IS - Insoluble

The infra-red spectral data of the Schiff bases are presented in Table 3. The characteristic band attributed to the respective aldehyde stretching $v(C=O)$ disappeared on the final Schiff bases and the new absorption band in the spectra of $\left(\mathrm{H}_{2} \mathrm{~L}^{\prime}\right)$ and $\left(\mathrm{H}_{2} \mathrm{~L}^{\prime \prime}\right)$ appeared at 1634 and $1638 \mathrm{~cm}^{-1}$ which were assign to frequency of $-\mathrm{C}=\mathrm{N}$ group for the respective compounds (Quaresma et al., 2017; Sani et al., 2018). The values obtained for $-\mathrm{C}=\mathrm{N}$ group were similar to the value reported by Nair and Joseyphus,(1644 $\left.\mathrm{cm}^{-1}\right)$ (Nair and Joseyphus, 2008). The two Schiff bases having additional characteristic functional group, the corresponding stretching vibration observed at $1176 \mathrm{~cm}^{-1}$ in the IR spectrum of $\left(\mathrm{H}_{2} \mathrm{~L}^{\prime \prime}\right)$ Schiff base is characterized due to C-O-C symmetric stretching of methoxy $\left(\mathrm{R}-\mathrm{O}-\mathrm{CH}_{3}\right)$. The phenolic $\mathrm{C}-\mathrm{O}$ stretching frequency of $\left(\mathrm{H}_{2} \mathrm{~L}\right)$ and $\left(\mathrm{H}_{2} \mathrm{~L}^{\prime \prime}\right)$ ligands is seen at 1256 and $1221 \mathrm{~cm}^{-1}$ respectively. The spectra of $\left(\mathrm{H}_{2} \mathrm{~L}^{\prime}\right)$ and $\left(\mathrm{H}_{2} \mathrm{~L}^{\prime \prime}\right)$ Schiff base ligands exhibit strong peak at 3385 and $3355 \mathrm{~cm}^{-1}$ which can be assigned to $\mathrm{O}-\mathrm{H}$ stretching vibration respectively. (Vadivel and Dhamodaran, 2016).

Table 3: Infrared spectral data of Schiff Bases $\left(\mathrm{cm}^{-1}\right)$

\begin{tabular}{cccccc}
\hline Compound & $\mathrm{v}(\mathrm{C}=\mathrm{N})$ & $\mathrm{v}(\mathrm{O}-\mathrm{H})$ & $\mathrm{v}(\mathrm{C}-\mathrm{O}-\mathrm{C})$ & $\mathrm{v}(\mathrm{C}-\mathrm{O})$ & $\mathrm{v}(\mathrm{C}-\mathrm{C})$ \\
\hline$\left(\mathrm{H}_{2} \mathrm{~L}^{\prime}\right)$ & 1634 & 3385 & - & 1256 & 1465 \\
$\left(\mathrm{H}_{2} \mathrm{~L}^{\prime \prime}\right)$ & 1638 & 3355 & 1176 & 1221 & 1521 \\
\hline
\end{tabular}


BAJOPAS Volume 12 Number 1, June, 2019

Figure 1shows the powder $\mathrm{x}$-ray diffraction patterns (PXRD) of the liquid-assisted mechanochemical compounds. The PXRD pattern of synthesized compounds were different from that of their respective reactants. New peaks corresponding to the mechanochemical product were observed in each of the Schiff base indicating the formation of new phase. Quantitative estimation of the $2 \theta$ PXRD patterns of the product $\left(\mathrm{H}_{2} \mathrm{~L}^{\prime}\right)$ and $\left(\mathrm{H}_{2} \mathrm{~L}^{\prime \prime}\right)$ were carried out. The major peaks in PXRD pattern of $\left(\mathrm{H}_{2} \mathrm{~L}\right)$ were observed at $2 \theta=17.14,24.79,25.30$, $27.08,29.38,40.34^{\circ} \mathrm{Cwhile}$ that of $\left(\mathrm{H}_{2} \mathrm{~L}^{\prime}\right)$ were observed at $2 \theta=8.984,11.17,13.36,14.67$, $17.1,19.71,22.55,24.08,25.72,26.38$, and $28.24^{\circ} \mathrm{C}$ (Figure 2), which were absent in the reactantsindicating formation of new phase of the product.

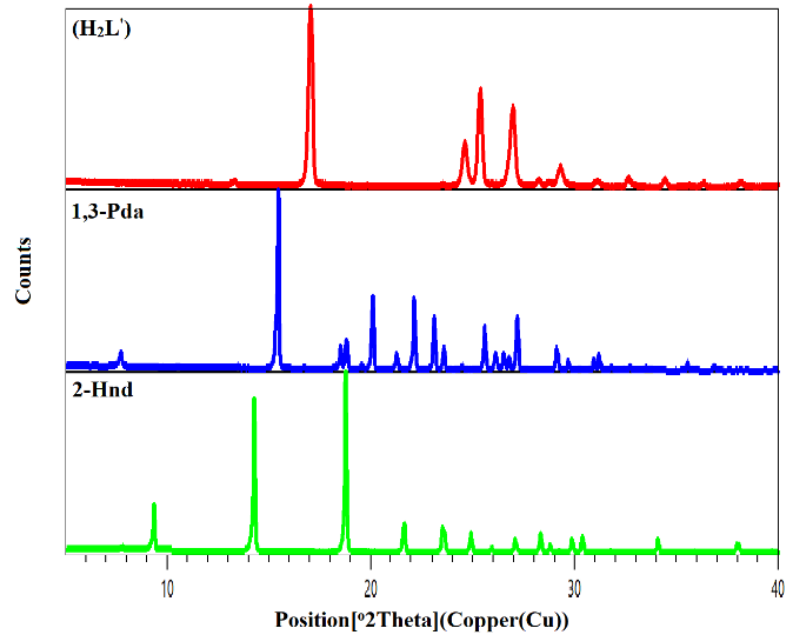

Figure 1: PXRD Patterns of 2-Hydroxy-1-naphthaldehyde (2-Hnd), 1,3-Phenylenediamine (1,3-Pda) and $\left(\mathrm{H}_{2} \mathrm{~L}^{\prime}\right)$ Schiff base

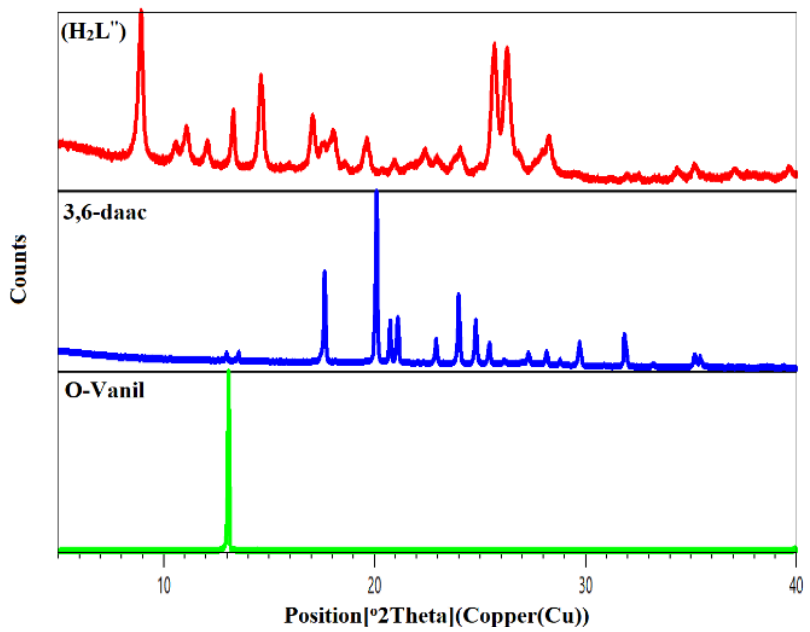

Figure 2:PXRD Patterns of 2-Hydroxy-3-Methoxy-benzaldehyde (O-Vanil), 3,6-Diaminoacridine (3,6Daac) and $\left(\mathrm{H}_{2} \mathrm{~L}^{\prime}\right)$ Schiff base

Energy Dispersive X-ray referred to as (EDX) can be used to determine the chemical elements present in the sample and used to estimate their relative abundance. The data generated by EDX analysis involve spectra showing peaks corresponding to the elements making up the true composition of the samples being analyzed. EDX results of $\mathrm{H}_{2}\left(\mathrm{~L}^{\prime}\right)$ Schiff base showed that, Carbon constitute the major atomic percent $74.47 \%$, followed by Oxygen $13.56 \%$ and
Nitrogen $11.97 \%$. For $\mathrm{H}_{2}\left(\mathrm{~L}^{\prime}\right)$ Schiff base, the atomic percent of Carbon, Oxygen and Nitrogen were found to be $69.31,18.38$ and $12.31 \%$ respectively(Table 4 ). The atomic percent of all the three component elements were compared in all the points analyzed and the result were found to be in agreement with each other indicating the uniform distribution of all the constituent elements in the sample compound (Figure 3). 
BAJOPAS Volume 12 Number 1, June, 2019

Table 4: Energy Dispersive x-ray (EDX) of Schiff Bases

\begin{tabular}{cccccc}
\hline Compound & Element & Weight (\%) & Atomic (\%) & K Ratio & Line type \\
\hline$\left(\mathrm{H}_{2} \mathrm{~L}^{\prime}\right)$ & $\mathrm{C}$ & 61.18 & 74.47 & 0.01405 & K Series \\
& $\mathrm{N}$ & 16.07 & 11.97 & 0.00084 & K Series \\
& $\mathrm{O}$ & 22.75 & 13.56 & 0.00174 & K Series \\
\hline$\left(\mathrm{H}_{2} \mathrm{~L}^{\prime}\right)$ & $\mathrm{C}$ & 65.33 & 69.31 & 0.00927 & K Series \\
& $\mathrm{N}$ & 12.95 & 12.31 & 0.00056 & K Series \\
& $\mathrm{O}$ & 21.72 & 18.38 & 0.00203 & K Series \\
\hline
\end{tabular}
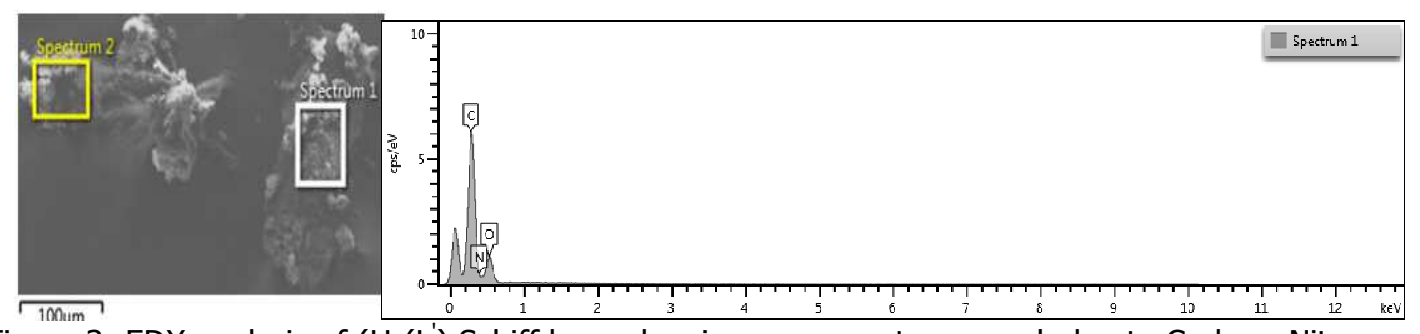

Figure 3: EDX analysis of $\left(\mathrm{H}_{2}\left(\mathrm{~L}^{\prime}\right)\right.$ Schiff base showing scan spectrum, peak due to Carbon, Nitrogen, and Oxygen in the Schiff base compound

The Schiff bases are also non-hygroscopic crystalline solids with different melting point.The DSC thermograms of Schiffbases displayed a single sharppeak at specific temperature, which is attributed to theendothermic melting or the phase transition, furthermore it suggested the purity of the synthesized compounds. DSC curve of $\mathrm{H}_{2}\left(\mathrm{~L}^{\prime}\right)$ and $\mathrm{H}_{2}\left(L^{\prime \prime}\right)$ Schiff bases shows oneendothermic peak at 123and $80.2^{\circ}$ Crespectively which corresponds to themelting point of the Schiff bases (Figure 4)

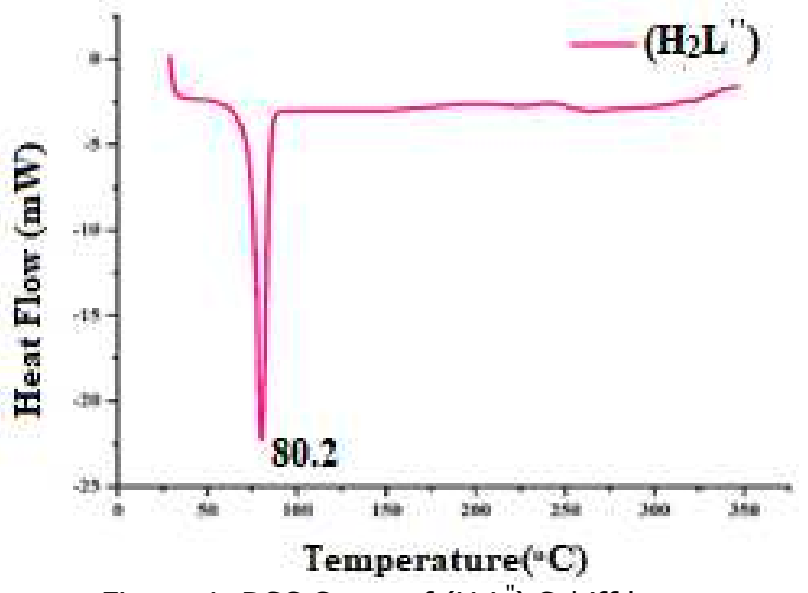

Figure 4: DSC Curve of $\left(\mathrm{H}_{2} \mathrm{~L}^{\prime \prime}\right)$ Schiff base

The results of antimicrobial sensitivity test revealed that $\left(\mathrm{H}_{2} \mathrm{~L}^{\prime}\right)$ Schiff base is more toxic to the tested bacterial strainsthan the $\left(\mathrm{H}_{2} \mathrm{~L}\right.$ ") Ligand. The highest inhibition of growth was observedat $60 \mathrm{mgml}^{-1}$ concentration against E. Col/gram negative), Table 5. (Figure 5). ( $\mathrm{H}_{2} \mathrm{~L}$ ") Schiff base shows weak antibacterial activity against $S$. aureus especially at lower concentration. On the other hand, $\left(\mathrm{H}_{2} \mathrm{~L}\right.$ ") Schiff baseshowed the best activity towards fungi, $C$. albicans and $A$. fumigatus, the highest activity was observed against C. albicans with inhibition of $17 \mathrm{~mm}$ at $60 \mathrm{mgml}^{-1}$ concentration (Figure 6). $\left(\mathrm{H}_{2} \mathrm{~L}\right.$ ') Schiff showed moderate activity against $A$. Fumigatus and lowest against $C$. albicans. (Table 7). The Azomethine group present in the Schiff base compounds has been shown to be responsible for their antimicrobial activities(Bringmann et al., 2004; Guo et al., 2007). 
BAJOPAS Volume 12 Number 1, June, 2019

Table 5:Antibacterial Sensitivity Test of Schiff Bases

\begin{tabular}{|c|c|c|c|c|c|c|}
\hline \multirow[t]{2}{*}{ Compound } & \multicolumn{3}{|c|}{$\begin{array}{c}\text { Escherichia Coli } \\
\text { Inhibition zone }(\mathrm{mm})\end{array}$} & \multicolumn{3}{|c|}{$\begin{array}{l}\text { Staphylococcus Aureus } \\
\text { Inhibition zone(mm) }\end{array}$} \\
\hline & $60 \mathrm{mgml}^{-1}$ & $30 \mathrm{mgml}^{-1}$ & $15 \mathrm{mgml}_{1}^{-}$ & $60 \mathrm{mgml}^{-1}$ & $30 \mathrm{mgml}^{-1}$ & $15 \mathrm{mgml}^{-1}$ \\
\hline Ciprofloxacin(Standard) & & 43 & & & 40 & \\
\hline DMSO (Control) & - & - & - & - & - & - \\
\hline$\left(\mathrm{H}_{2} \mathrm{~L}^{\prime}\right)$ & 16 & 14 & 10 & 14 & 10 & 8 \\
\hline$\left(\mathrm{H}_{2} \mathrm{~L}^{\prime \prime}\right)$ & 13 & 9 & - & 11 & - & - \\
\hline
\end{tabular}

Table 6:Antifungal Sensitivity Test of Schiff Bases

\begin{tabular}{|c|c|c|c|c|c|c|}
\hline \multirow[t]{2}{*}{ Compound } & \multicolumn{3}{|c|}{$\begin{array}{c}\text { Candida albican } \\
\text { Inhibition zone }(\mathrm{mm})\end{array}$} & \multicolumn{3}{|c|}{$\begin{array}{l}\text { Aspergillus Fumigatus } \\
\text { Inhibition zone }(\mathrm{mm})\end{array}$} \\
\hline & $60 \mathrm{mgml}^{-1}$ & $30 \mathrm{mgml}^{-1}$ & $15 \mathrm{mgml}_{1}^{-}$ & $60 \mathrm{mgml}^{-1}$ & $30 \mathrm{mgml}^{-1}$ & $15 \mathrm{mgml}^{-1}$ \\
\hline $\begin{array}{c}\text { Ketoconazole } \\
\text { (Standard) }\end{array}$ & & 43 & & & 40 & \\
\hline DMSO (Control) & - & - & - & - & - & - \\
\hline$\left(\mathrm{H}_{2} \mathrm{~L}^{\prime}\right)$ & 10 & - & - & 12 & 11 & 8 \\
\hline$\left(H_{2} L^{\prime \prime}\right)$ & 17 & 15 & 12 & 16 & 14 & 11 \\
\hline
\end{tabular}

Figure 5: Showing image of Antibacterial inhibition zone of $\left(\mathrm{H}_{2} \mathrm{~L}^{\prime}\right)$ Schiff base tested against $E$. Coli

Figure 6: Showing image of Antifungal inhibition zone of $\left(\mathrm{H}_{2} \mathrm{~L} "\right)$ Schiff base tested against $A$.

Fumigatus

\section{CONCLUSION}

The liquid-assisted mechanochemical synthesis of Schiffbase reportedin this paper is effective in giving excellent conversion to theproduct, lessenergy consuming. The synthesized compounds were characterized by FT-IR, Powder XRD, EDX, DSC and CHN microanalysis. There is virtually no work-up necessary during isolationof the Schiffbase. The antimicrobial activity test of the synthesized compounds showed moderate to good activity against the organism tested.

\section{Contribution of Authors}

The work was carried out in collaboration between allthe reported authors. Sani, S. designed theexperiment and did theexperimental work. Kurawa, M. A. and Siraj I. T. 
BAJOPAS Volume 12 Number 1, June, 2019

Supervised and Co-supervised the research work. Koki, I. B. contributed to the literature search. All authorsaccepted the final version of the manuscript.

\section{REFERENCES}

Aspa, J., Rajas, O., de Castro, F.R., 2008. Pneumococcal antimicrobial resistance: therapeutic strategy and management in community-acquired pneumonia. Expert opinion on pharmacotherapy 9, 229241.

Braga, D., Giaffreda, S., Curzi, M., Maini, L., Polito, M., Grepioni, F., 2007. Mechanical mixing of molecular crystals: A green route to co-crystals and coordination networks. Journal of Thermal Analysis and Calorimetry 90, 115-123.

Bringmann, G., Dreyer, M., Faber, J.H., Dalsgaard, P.W., Stla erk, D., Jaroszewski, J.W., Ndangalasi, H., Mbago, F., Brun, R., Christensen, S.B., 2004. Ancistrotanzanine $C$ and Related 5, 1 '-and 7, 3 '-Coupled Naphthylisoquinoline Alkaloids from Ancistrocladus $t$ anzaniensis. Journal of natural products 67, 743-748.

Cinčić, D., Kaitner, B., 2011. Schiff base derived from 2-hydroxy-1-naphthaldehyde and liquid-assisted mechanochemical synthesis of its isostructural $\mathrm{Cu}$ (II) and Co (II) complexes. CrystEngComm 13, 4351-4357.

Friščić, T., 2010. New opportunities for materials synthesis using mechanochemistry. Journal of Materials Chemistry 20, 7599-7605.

Friščić, T., Trask, A.V., Jones, W., Motherwell, W.S., 2006. Screening for inclusion compounds and systematic construction of three-component solids by liquidassisted grinding. Angewandte Chemie International Edition 45, 7546-7550.

George, R.S., Joseph, R., George, K.E., 1993. Study of polyschiff's base as a protective agent in natural rubber. International Journal of Polymeric Materials 23, 1726.

Guo, Z., Xing, R., Liu, S., Zhong, Z., Ji, X., Wang, L., Li, P., 2007. Antifungal properties of Schiff bases of chitosan, $\mathrm{N}$ substituted chitosan and quaternized chitosan. Carbohydrate Research 342, 1329-1332.

James, S.L., Adams, C.J., Bolm, C., Braga, D., Collier, P., Friščić, T., Grepioni, F.,

\section{Conflict of interest}

Authorsdeclare that, there is no conflict of interest.

Harris, K.D., Hyett, G., Jones, W., 2012. Mechanochemistry: opportunities for new and cleaner synthesis. Chemical Society Reviews 41, 413-447.

Nair, M.S., Joseyphus, R.S., 2008. Synthesis and characterization of $\mathrm{Co}$ (II), $\mathrm{Ni}$ (II), Cu (II) and Zn (II) complexes of tridentate Schiff base derived from vanillin and DLa-aminobutyric acid. Spectrochimica Acta Part A: Molecular and Biomolecular Spectroscopy 70, 749-753.

Patil, V., Singh, A., Naik, N., Unnikrishnan, S., 2014. Estimation of carbon stocks in Avicennia marina stand using allometry, CHN analysis, and GIS methods. Wetlands 34, 379-391.

Quaresma, S., André, V., Fernandes, A., Duarte, M.T., 2017. Mechanochemistry-a green synthetic methodology leading to metallodrugs, metallopharmaceuticals and bio-inspired metal-organic frameworks. Inorganica Chimica Acta 455, 309-318.

Sachdeva, H., Saroj, R., Khaturia, S., Dwivedi, D., 2012. Operationally simple green synthesis of some Schiff bases using grinding chemistry technique and evaluation of antimicrobial activities. Green Processing and Synthesis 1, 469477.

Sani, S., Kurawa, M.A., Siraj, I.T., 2018. Solid State Synthesis, Spectroscopic and X-ray Studies of Cu (II) Schiff base Complex Derived from 2-Hydroxy-3methoxybenzaldehyde and 1, 3Phenylenediamine. ChemSearch Journal 9, 76-82.

Stolar, T., Batzdorf, L., Lukin, S., Žilić, D., Motillo, C., Friščić, T., Emmerling, F., Halasz, I., Užarević, K., 2017. In situ monitoring of the mechanosynthesis of the archetypal metal-organic framework HKUST-1: Effect of liquid additives on the milling reactivity. Inorganic chemistry 56, 6599-6608.

Vadivel, T., Dhamodaran, M., 2016. Synthesis, characterization and antibacterial studies of ruthenium (III) complexes derived from chitosan Schiff base. International journal of biological macromolecules 90, 44-52. 